\title{
Cuizine
}

The Journal of Canadian Food Cultures

Revue des cultures culinaires au Canada

\section{The Food and Folklore Reader, Lucy M. Long (editor), Bloomsbury Academic, 2015, 467 p.}

\section{Debra Wain}

Volume 8, numéro 1, 2017

URI : https://id.erudit.org/iderudit/1046628ar

DOI : https://doi.org/10.7202/1046628ar

Aller au sommaire du numéro

Éditeur(s)

McGill University Library

ISSN

1918-5480 (numérique)

Découvrir la revue

Citer ce compte rendu

Wain, D. (2017). Compte rendu de [The Food and Folklore Reader, Lucy M. Long (editor), Bloomsbury Academic, 2015, 467 p.] Cuizine, 8(1).

https://doi.org/10.7202/1046628ar d'utilisation que vous pouvez consulter en ligne.

https://apropos.erudit.org/fr/usagers/politique-dutilisation/ 


\section{The Food and Folklore Reader, Lucy M. Long (editor), Bloomsbury}

Academic, 2015, 467 p.

\section{Debra Wain}

Lucy M. Long's collection of essays in The Food and Folklore Reader draws on various fields of thought in the ethnographic study of food and folkloristics, which is discussed as originally being the study of "folk foods" leading to the study of "folklore about food" and then expanded to include "food as folklore" (1). This collection brings together essays and articles that have previously appeared in various notable journals such as American Journal of Sociology, Western Folklore, and Food and Foodways; in books on ethnicity, folklore and food such as Food and Festival in American Life, Culinary Tourism, and Useable Pasts: Traditions and Group Expression in North America; and as presentations at conferences such as the Oxford Symposium on Food and Cookery, and the Conference of the International Commission for Ethnological Food Research. The collection presents the ways that food establishes connections to religious, political and economic elements of daily life; to place, our pasts-both nostalgic and historical, and others in our communities; and to natural cycles, physical space, and the planet.

The book is meticulously organised into five parts. Each part of this text is replete with a section introduction, an introduction to the readings included in the section, and a set of discussion questions. All of which make this collection an ideal text for inclusion in undergraduate courses of ethnographic study. 
The collection of ideas presented within the text are expansive, encompassing 45 different contributors and covering topics ranging from ethnographic methodologies (see Part I), to the aesthetics of culinary work (see in particular a number of chapters in Part III), to food and foodways as socio-cultural artefacts (see for example Janet Theophano's discussion of food as communication and Eve Jochonowitz's examination of Jewish cuisine, both in Part IV). There appears, within a number of the pieces included in this collection, the notion of the way that the folkloristics of food negotiate social and cultural expectations. The importance of these expectations are expounded upon in relation to diaspora, status, identity and tradition in many chapters, for example those by Margaret Magat, Anne Kaplan, and Michael Owen Jones.

Introductions to the history and methodologies pertinent to the area of study make up the content of "Part I: Foundations: History, Definitions and Methodologies" where these aspects of the area of study are clearly identified and described for the reader. Definitions of relevant terms are provided and an analysis of methodologies from the 1700s to the present day are detailed.

"Part II: Food in Groups, Community, and Identity" takes snapshots of the cultural importance of food and foodways from various points on the globe. The articles included here range from analyses of foodways from particular communities in the United States of America, to conference proceedings in Norway; from a discussion of food and identity in Canada, to the significance of fertilised duck eggs in the Philippines and meat pies in Australia. As a reader located in the land of meat pies and tomato sauce, I found the inclusion 
of Australasian cuisine refreshing but the main focus of the collection is on aspects of food, foodways and folklore in North America.

The ability of food to represent wider ideas and to stand for things greater than the simple act of physical nourishment is explored in Part III called "Food as Art, Symbol, and Ritual". This is where food's relationship to Art, or food as Art, is discussed as well as its symbolism and significance to particular cultural festivals. The artistic processes and aesthetic choices and responses to different foods are also covered in this section, as are the processes of meaning-making, and the aesthetics of taste and distaste.

"Part IV: Food as Communication, Performance, and Power" elucidates the hierarchies that food can represent and the power dynamics inherent in these strata, as well as food and foodways as means by which groups can be oppressed or how they resist such oppression. The articles within this section deal particularly with what, and how, food communicates in relation to specific rituals, etiquettes, and understandings. The performance aspect of this section discusses food as a performance of place, identity, memory, time and gender. Of particular interest here, is the ways such performances are interpreted or misinterpreted by those who act as audience or receiver of these food-conveyed messages such as the confusion created when cultural offers of food and polite refusal do not match as is mentioned in Amy Shuman's chapter called "The Rhetoric of Portions”.

The final section, "Part V: Food in Public and Applied Folklore" takes food as folklore beyond traditions towards tourism and reaches out from the 
academic realm toward more practical applications with a particular focus on sustainability in its various guises by discussing the sustainability of both food products or ingredients and the communities to whom they are significant. The role of food and foodways practices in relations to identity formation and performance is negotiated here alongside the politics of representation and inclusion, as well as access to and ownership of different foods and food products. Food is explored as an important element within the economic development and branding of a place or region where tradition comes into play.

The final piece in this collection of insightful essays comes from Margaret Yocom and consists of two poems and an artist's statement which reminds the folklorist and the folkloristics student that when they enter the "field" they must "take tools with [them] according to [their] talents to help [them] attend..." and that "[e]thnographic practice is a moral practice" (452). The inclusion of ethnopoetics at this point acts as a reminder to the ethnography student that there are myriad means by which to conduct this moral practice of recording the lives of others and the role of food within those lives. It reminds us that the shapes that ethnography and folkloristics can take are as diverse as the dishes of our cuisines. The range of topics covered in this collection of essays and articles is broad making it a useful text around which a course of study could be built. It works well as an introduction to a number of methods, principles, theories, and aspects of food, foodways and folkloristics. 


\section{Biography}

\section{Biographie}

Debra Wain holds a PhD in Creative Writing from Deakin University. Her research interests include women, food and culture, which she investigates through short stories. Her work - which has appeared in Landlines:

anthology of regional poets, Verandah, Tincture, Verity La and Meniscus - is often inspired by the Australian communities in which she has lived. Debra is a current sessional academic at Deakin University, University of New England and La Trobe University, Australia.

Debra Wain détient un doctorat en création littéraire de l'Université Deakin. Ses recherches portent notamment sur les femmes, l'alimentation et la culture, qu'elle examine par le biais de courts récits. Ses travaux - qui ont été publiés dans Landlines: anthology of regional poets, Verandah, Tincture, Verity La et Meniscus - s'inspirent souvent des communautés australiennes au sein desquelles elle a vécu. Debra enseigne présentement à temps partiel à l'Université Deakin, à la University of New England et à l'Université La Trobe, en Australie. 